\title{
Storming the Hill: North Carolina Librarians Become Lobbyists for a Day
}

"It was exciting!"

"I felt I made a difference."

"It was empowering."

"It is probably one of the most important things I have ever done as a librarian."

These and similar reactions were shared by six librarians from North Carolina who participated in "Plant Grassroots @ Your Library" on May 7, 2002, the 28th annual National Library Legislative Day sponsored by the American Library Association (ALA) to put librarians and legislators in touch with each other. Librarians from all over the United States converged on Washington, DC, to meet their legislators and discuss issues important to libraries and their constituents. North Carolina was represented by Nancy Gibbs of Duke University, Peggy Hoon of North Carolina State University, Linda McDaniel of Harnett County Public Schools, Ann Miller of Duke University, Allan Scherlen of Appalachian State University, and John Via of Forsyth County Public Library. As chair of the North Carolina Library Association's Governmental Relations Committee, Peggy Hoon coordinated the event, organizing her troops and making appointments for visits with legislators.

Most of the North Carolina delegation had participated before and knew what to expect. The only rookie, Allan Scherlen, was concerned about not being sufficiently informed about the details of issues to be an effective advocate. He and other newcomers discovered that the job of advocacy is easier than one might expect. ALA sponsored briefing sessions the day before National Library Legislative Day, giving delegates fast track summaries of the issues. The discussions were reinforced with concise handouts of the key points of legislation and "talking points" of what libraries want from their legislators. Allan says he emerged from the sessions confident and ready to "storm the hill."

Delegates were asked to focus on a few core issues, including passage of the Museum and Library Services Act of 2002, which includes re-authorization of the Library Services and Technology Act (LSTA); passage of the "TEACH Act," which updates the distance education provisions of the Copyright Act in light of advances in digital transmission technologies that support distance learning; and various copyright issues, including the database protection legislation being proposed by North Carolina Representative 
Howard Coble and others, which would include broad language providing protection for commercial databases and potentially denying free access to basic factual information in the public domain. Academic librarians also brought to the table the chilling effect on scholarship of Presidential Executive Order 13233, which claims executive privilege over past presidential records beyond the 12-year limit. They encouraged legislators to support HR 4187, "Further Implementation of the Presidential Records Act," which would annul it.

Tuesdays are reserved in Congressional offices for visits by individuals and groups lobbying for certain issues, and the halls were packed with staffers and lobbyists. Staffers specializing in legislation affecting libraries welcomed the librarians and talked with them about the issues raised, asking questions and taking detailed notes. Staff members commented that it was great to meet the people behind the issues and that it gave them a better perspective of constituents' concerns. Staffers were delighted to receive the packet of information prepared by the State Library of North Carolina which detailed exactly how LSTA funds have been used in their districts. Ann Miller and Allan Scherlen were fortunate to be in Representative Howard Coble's (R-NC, 6th Dist.) office when he was present and to have the opportunity to talk to him directly. He brought in the council for the House Judiciary Committee to participate in the discussion of the database protection legislation, and some lively debate ensued. Delegates also saw Representative Bob Etheridge (D-NC, $2 d$ Dist.) briefly and ran into Representative Mel Watt (D-NC, 12th Dist.) in the elevator.

There were several opportunities to interact more informally with colleagues and legislative personnel. NCLA hosted a luncheon for North Carolina delegates and staffers on Legislative Day, and at the end of the day ALA sponsored a reception for all delegates, legislators, and staff members. Representative Coble attended, the only North Carolina legislator to do so.

Delegates strongly emphasize that follow-up is important. Once you have made personal contact with legislators and staffers you should write, e-mail, or call them regularly. You are now more than just a name, and your support and suggestions have more weight. You may be asked for input. Allan Scherlen says he hopes to develop good working relationships with the staffers he met and looks forward to participating next year.

It is crucial to offer support as well as to ask favors. Nancy Gibbs urges librarians to go to public forums and to invite legislators to visit their libraries when they are "home."

North Carolina needs more librarians to participate in this exciting opportunity to experience the democratic process first hand. It is amazing how powerful you can be in affecting legislation if you tell your story to your representatives. Shortly after their visit, a staff member for Representative David Price (D-NC, 4th Dist.) called Ann Miller to let her know that he had signed on as a co-sponsor for HR 4187. "I'd like to think our visit and Allan's impassioned arguments made a difference!" she said. To join the delegation next year, monitor the NCLA listserv (ncla-1@soe.ecu.edu) or contact Peggy Hoon, Chair, Governmental Relations Committee, at 919-513-2045. As Nancy Gibbs commented, "It was fantastic. Nobody can look you in the face and say they're against libraries!" 